\title{
Trap Fishery and Reproductive Biology of the Whitespotted Rabbitfish Siganus sutor (Siganidae), within the Dar es Salaam Marine Reserves, Tanzania
}

\author{
A.T. Kamukuru \\ Department of Aquatic Sciences and Fisheries, University of Dar es Salaam, P.O. Box 60091, Dar es Salaam, \\ Tanzania
}

Keywords: Trap fishery, rabbitfishes, Siganus, reproduction, marine reserves, Tanzania

\begin{abstract}
Fish samples and catch data were collected monthly from traditional basket fish traps set on reefs within the Dar es Salaam Marine Reserves (DMRs) to evaluate trap catch dynamics and reproductive biology of the rabbit fish Siganus sutor (Valenciennes 1835). Trap catch composition was $85 \%$ rabbitfishes by weight with a mean $( \pm$ SE) catch per unit effort (CPUE) of $2.8 \pm 0.1 \mathrm{~kg}$ trap $^{-1}$ day $^{-1}$ during a fishing season, which lasted between September 2004 and May 2005. CPUE did not differ significantly with lunar cycle, but exhibited a spatial variation, the highest being from Fungu Yasini Marine Reserve, which is further from shore. The spawning season of S. sutor is protracted, lasting between October and May, peaking in March. Size at first sexual maturity was 217.1 and $227.7 \mathrm{~mm}$ TL for male and female $S$. sutor, respectively. The species exhibits a size-dependent sex ratio, with a preponderance of females at larger sizes. The species shows high fecundity at a maximum of $1,300,400$ oocytes for $396 \mathrm{~mm}$ TL female. Average ( \pm SE) total fecundity was $627,052 \pm 78,886$ oocytes per female of 266 to $396 \mathrm{~mm}$ TL. It is proposed that beach seines be eliminated from the marine reserves and regulated trap fishery be allowed as a way to facilitate sustainable exploitation of the rabbitfishes and other reef fishes in the DMRs.
\end{abstract}

\section{INTRODUCTION}

Traditional trap fishing is one of the main sources of income and animal protein for coastal people in East Africa (King, 2000). Yields from the shallow reef fisheries have been declining mostly as a result of overfishing caused by poor fishing methods and increased effort (McClanahan \& Mangi, 2001; Kamukuru et al., 2004, 2005). It is widely recognised that fishing leads to changes in the abundance of target species manifested by decreases in sizes and catch per unit effort (CPUE) within the fishery (Koslow et al., 1988; Alcala \& Russ, 1990; Kamukuru et al., 2005). Global fisheries statistics show that after depleting large and slow-growing fishes at higher food webs, fisheries increasingly rely on smaller and fast-growing fishes at lower trophic levels (Sibert et al., 2006). This, "fishing down the marine food web" (see Pauly et al., 2005) presents exploitation patterns that are unsustainable.

In East Africa, hexagonal basket fish traps (madema) woven from wood and split bamboo are commonly used by artisanal fishers. McClanahan \& Mangi (2004) describe two basket trap sizes, as either small $(1.2 \times 1 \times 0.2 \mathrm{~m})$ or big $(2 \times 1.3 \times$ $0.3 \mathrm{~m}$ ), in terms of length, width and height with a mesh size of about 3 or $5 \mathrm{~cm}$, respectively. Fishing techniques entail placement of baited traps (using an assortment of green algae and animal tissues) on the reef flat, in sandy lagoon areas interspersed with seagrasses and coral rubble to target reef fishes. In order to maintain position and appear as a refuge 
the traps are covered by broken fragments of rock and coral. They are usually hauled on a daily basis, but sometimes are left in water for more than a day depending on prevailing weather conditions.

Wild siganids are an important human food source with reported catch of 480 tonnes in 1981 in the Western Indian Ocean region (Fischer \& Bianchi, 1984). Their fast growth rate (KaundaArara \& Rose, 2006), diurnal schooling behaviour and browsing in shallow water habitats make them ideal for trap fishery and aquaculture (Woodland, 1990).

Some data on the seasonal reproduction of the whitespotted rabbitfish, Siganus sutor, are available for the Kenyan coast (Ntiba \& Jaccarini, 1990, 1992). However, Bwathondi (1981) reported that siganids breed throughout the year in Tanzanian coastal waters. There is limited information on the fishery of $S$. sutor, the most commercial siganid, from Eastern Africa and most of the WIO region. The present study investigated variations in CPUE and size structure of $S$. sutor from trap fishery within the Dar es Salaam Marine Reserves and provides additional information on reproductive parameters of the species.

\section{MATERIALS AND METHODS}

\section{Study area}

Dar es Salaam Marine Reserves (DMRs) refer to a set of three island reserves of Bongoyo, Mbudya and Pangavini and,Fungu Yasini sand bank (Fig. 1). DMRs were gazetted in June 1975, however, little effort has been made to conserve their habitats and ensure sustainable resource use (URT, 2005). DMRs are shallow reef areas (less than $20 \mathrm{~m}$ deep) in which four sites namely Mbudya, Pangavini, Fungu Yasini and Fungu Mkaji were studied between September 2004 and May 2005. Study sites were chosen because they were considered typical coral reef areas targeted by migrant trap fishers from Unguja Island in Zanzibar.

\section{Data collection}

Fish caught in basket traps of mesh size of $5 \mathrm{~cm}$ set overnight in $<15 \mathrm{~m}$ depth were weighed on a suspended spring balance to the nearest $0.5 \mathrm{~kg}$. Catch was sorted into rabbitfishes and non-targeted fish categories. Catch data were recorded over 12 days for each lunar month (i.e. three consecutive days for each new moon, full moon, first quarter and last quarter) for the entire fishing season. Information on the number of fishers per boat, traps per boat and fishing grounds were provided by fishers. Individuals of $S$. sutor were also collected from beach seines of mesh size $1.5 \mathrm{~cm}$ and $4 \mathrm{~cm}$ at the bunt and wings respectively frequently used by fishers in weedy shallow waters adjacent to DMRs. Data from the two fishing gear were used to compare length-frequency distributions and size at first capture of $S$. sutor.

S. sutor was measured for total length (TL) on a fish measuring-board to the nearest millimetre. Total weight (TW) and eviscerated weight (EW) were measured to the nearest gram using a toploading digital balance. Paired gonads were weighed to the nearest $0.1 \mathrm{~g}$. Macroscopic gonadal maturation staging followed the key by Ntiba \& Jaccarini (1990). Paired ovaries at maturity stages IV and $\mathrm{V}$ were preserved in cross-referenced plastic bottles containing Gilson's fluid for fecundity determination. Contents of the bottles were kept at room temperature for three months with a constant vigorous shaking to allow release of eggs from ovarian tissues. Presence or absence of viscera fats (VF) surrounding the gonads and gut was recorded for every individual fish examined. Gonadosomatic indices (GSI) were determined as:

$$
\text { GSI }=\frac{\text { Paired gonad weight }}{\text { Eviscerated weight }} \times 100
$$

Total fecundity $(F)$ of each female was obtained by counting standing stock of advanced yolked oocytes in ripening ovaries using a volumetric method (Kamukuru \& Mgaya 2004) as:

$$
\mathrm{F}=\frac{\mathrm{V} \times \mathrm{n}}{\mathrm{V}}
$$

where $V$ is volume to which the total number of yolked oocytes was made up, $n$ is the mean number of yolked oocytes in ten aliquots, and $v$ is the volume of sub-sample. The length at which $50 \%$ of the fish were mature (Stage III and above) was regarded as the size at first sexual maturity $\left(\mathrm{L}_{\mathrm{M} 50}\right)$. The $\mathrm{L}_{\mathrm{M} 50}$ was estimated by fitting the fraction of mature individuals per $10 \mathrm{~mm}$ TL intervals to an 


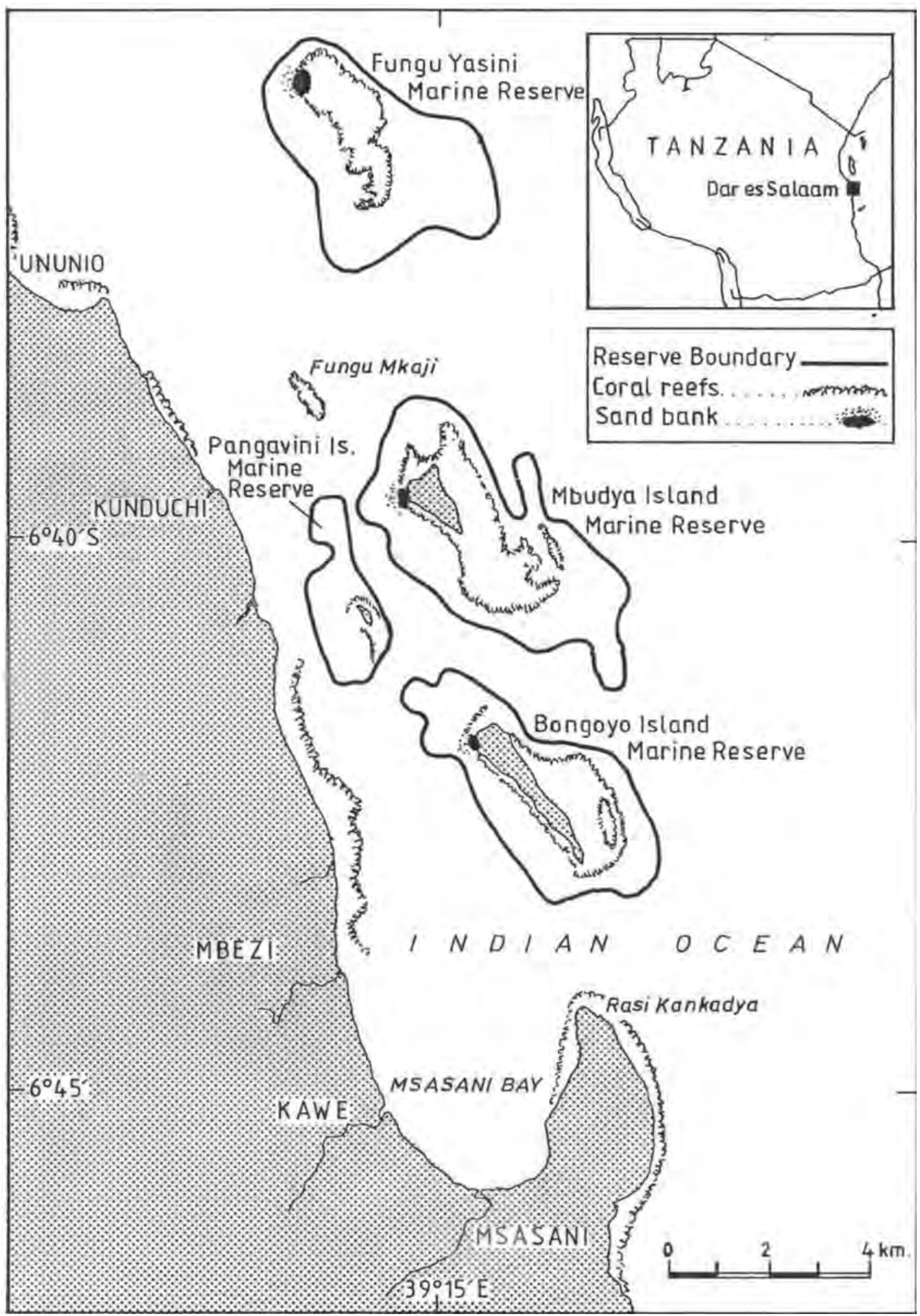

Fig. 1. Map of the Dar es Salaam Marine Reserves (DMRs) showing Mbudya, Pangavini and Fungu Yasini Marine Reserves and Fungu Mkaji study sites 
ogive function by non-linear regression weighted by the total number of individuals in each size class (Duponchelle \& Panfili, 1998):

$$
\% \mathrm{MF}=\frac{1}{1+\mathrm{e}^{\left(-\mathrm{a}\left(\mathrm{L}-\mathrm{L}_{\mathrm{M} 50}\right)\right)}}
$$

where $\% M F$ is the percentage of mature fish by size class, $L$ is the mid length of each size class, $a$ and $L_{M 50}$ are constants for the model. Size at first capture was determined using the method by Pauly (1984). In addition, seawater temperature was recorded using a temperature logger placed at $2 \mathrm{~m}$ depth, recording daily temperature over 4.8 hours per day.

\section{Data analyses}

Average number of fishing boats, fishers, traps, CPUE and fish lengths were compared among months, sites and lunar phases and fishing areas using single factor ANOVA and post-hoc test followed the Turkey honestly significant difference (HSD) test. Normality of the data was checked with the Shapiro-Wilkinson test and homogeneity of variances was determined with a Levene's test using SPSS 15.0 for Windows (SPSS Inc., 2006). All data that did not show homogenous variances were $\log (x+1)$ transformed before analysis. Sex ratio of $S$. sutor was analysed using the Chi-square test. The least squares regression analysis was used to investigate the relationships between fish length and fecundity and between length and weight.

\section{RESULTS}

A total of $13,033.5 \mathrm{~kg}$ of fish was recorded from basket traps operating in DMRs within 94 sampling days lasting between September 2004 and May 2005. Rabbitfishes, mainly S. sutor, constituted $85.6 \%$ of the catch with others making the remaining $14.4 \%$ by weight. The other groups caught in the traps were parrotfishes (Scaridae), wrasses (Labridae), surgeonfishes (Acathuridae), goatfishes (Mullidae), emperors (Lethrinidae), triggerfishes (Balistidae), grunts (Haemulidae), snappers (Lutjanidae), groupers (Serranidae) and rays (Dasyatidae). The mean number of fishing boats, fishers per boat and traps per boat varied between months, as seen in Figure 2a (ANOVA, $d f$ $=8 ; p<0.001 ; F=332.5,10.6$ fishers per boat and
5.5 traps per boat). CPUE of total catch, rabbitfishes and others, also varied between months (see Fig. 2b) (ANOVA, $d f=8 ; p<0.001 ; F=24.2,29.7$ for total catch and 6.1 for rabbitfishes and others). There was significant variations in CPUE between the fishing sites (ANOVA: $d f=3 ; p<0.001 ; F=8.1$ and 7.9 respectively for total catch and rabbitfishes) with a marked difference in CPUE between Fungu Yasini and Mbudya Island (Fig. 3a). No significant difference was found in CPUE of other fish groups caught at fishing sites (ANOVA: $d f=3 ; F=0.05$; $p>0.05$ ). The CPUE did not differ significantly between the four phases of the lunar cycle (Fig. 3b) (ANOVA: $d f=3 ; F=1.5 ; p>0.05$ for total catch and rabittfishes and $F=1.8 ; p>0.05$ for others). Mean TL of $S$. sutor varied significantly between fishing areas (ANOVA: $d f=3 ; F=46.2 ; p<0.001$ ) with no significant difference between Fungu Yasini and Mbudya Island (Fig. 4a). Mean total length of $S$. sutor also varied significantly between months (ANOVA: $d f=8 ; F=22.6 ; p<0.001$ ) with the lowest mean length recorded in May towards the end of fishing season (Fig. 4b).

The overall length-weight relationship of $S$. sutor was TW $=0.00002 \times \mathrm{TL}^{2.973}$. A Student $t$-test for the cube law of length-weight relationship indicates $S$. sutor to exhibit an isometric growth $(t=-1.131 ; d f=541 ; p>0.05)$. The sex ratio of $S$. sutor caught in basket traps was 1:0.8 being significantly in favour of females $\left(\chi^{2}=6.6 ; d f=\right.$ $1 ; p<0.01)$. Females predominated in larger size classes between 207 to $432 \mathrm{~mm}$ TL $\left(\chi^{2}=12.6 d f\right.$ $=1 ; p<0.001)$ while males dominated in smaller size classes between 162 and $192 \mathrm{~mm}$ TL $\left(\chi^{2}=\right.$ 7.7; $d f=1 ; p<0.01)$. Seasonal variations in GSI, occurrence of VF (Fig. 5a), gonad maturity stages and seawater temperature (Fig. 5b) were used to predict spawning periodicity of S. sutor. GSI peaked in March corresponding to higher proportion of fish with ripe gonads (Stages IV and V), which occurred during warmer months (see Fig. 5b). Total fecundity of $S$. sutor ranged from 99,100 to $1,300,400$ oocytes with an average $( \pm$ SE) of $627,052 \pm 78,886$ oocytes per female fish between 266 and $396 \mathrm{~mm}$ TL. Fish length-fecundity (F) relationship was exponential $\left(F=1 \mathrm{E}-13 T L^{5.5} ; d f=23 ; F=26.1 ; R^{2}=0.5 ; p<\right.$ 0.001 ) while fish weight-fecundity relationship was linear $(F=2830.9 W-574143 ; d f=23 ; F=66.5$; 


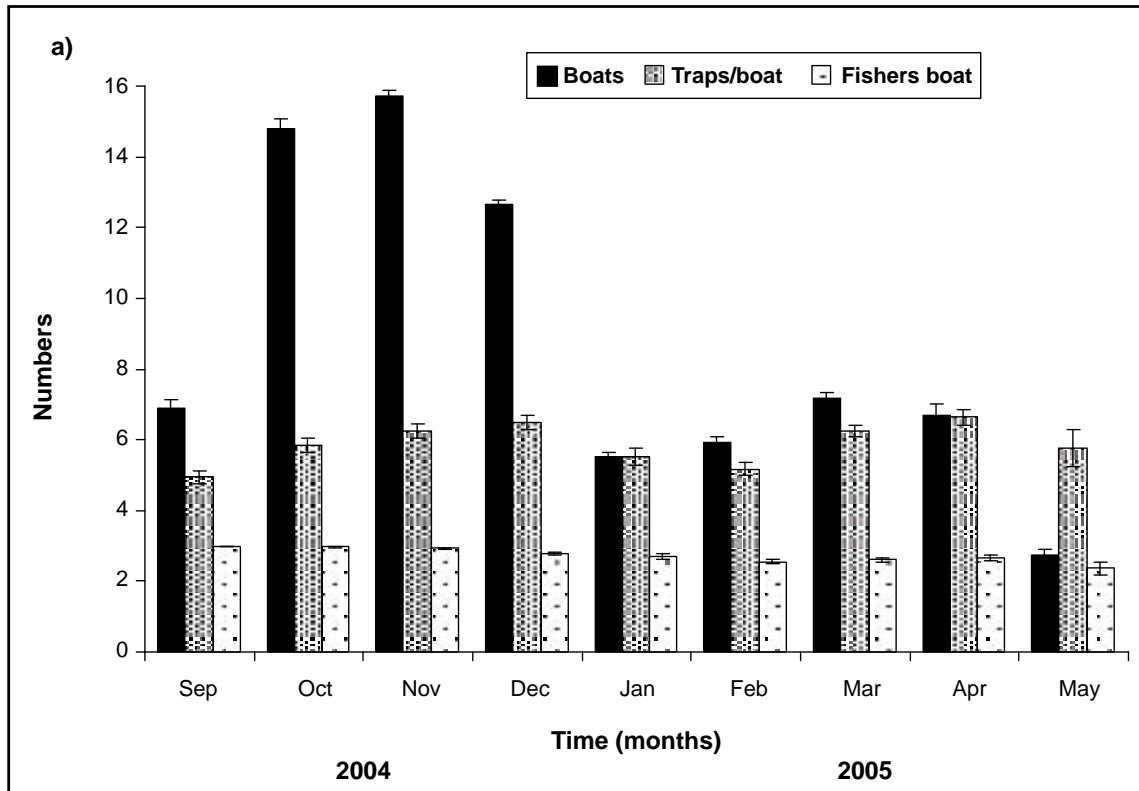

b)

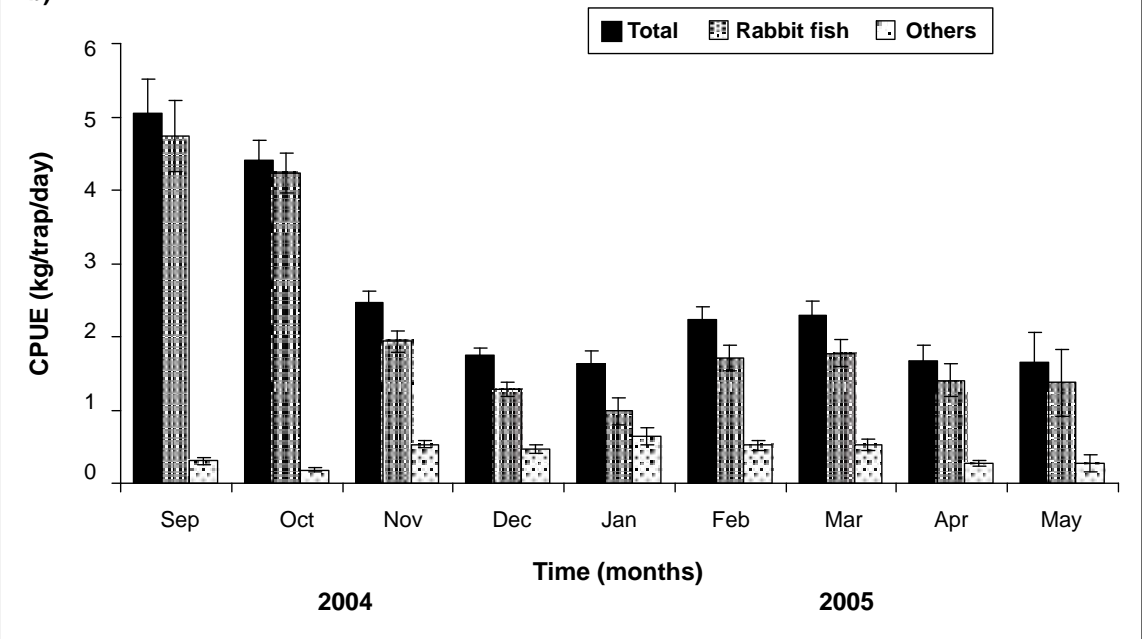

Fig. 2. Monthly variations in a) number of fishing boats, traps per boat and fishers per boat and b) CPUE in the Dar es Salaam Marine Reserves. Bars are standard errors (SE) of the mean

$\left.R^{2}=0.7 ; p<0.001\right)$. The minimum size of mature male and female $S$. sutor was 203 and $216 \mathrm{~mm}$ TL with size at first sexual maturity at 217.1 and 227.7 mm TL, respectively (Fig. 6). Basket traps caught S. sutor of significantly higher mean $( \pm$ SE) 262.0 $\pm 1.8 \mathrm{~mm}$ TL (range, 163 and $435 \mathrm{~mm}$ TL) than beach seines at mean $107.3 \pm 1.3 \mathrm{~mm} \mathrm{TL}(t=-69.3$; $d f=765 ; p<0.001)$. Size at first capture of $S$. sutor was 92.3 and $240.4 \mathrm{~mm}$ TL from beach seines and basket traps, respectively (Fig. 7).

\section{DISCUSSION}

Rabbitfishes constituted $85 \%$ by weight of fish caught in basket traps within DMRs. Roxburgh et al. (2002) reported rabbitfishes to constitute up to $32 \%$ by weight from all of the fishing gear in the study area. These results suggest that the DMRs have a high abundance of Siganidae. The impact of the Asian tsunami of December 26, 2004 on the Tanzanian coast likely explains a dramatic decrease 
a)

\section{Total 橉 Rabbitfish $\square$ Others}

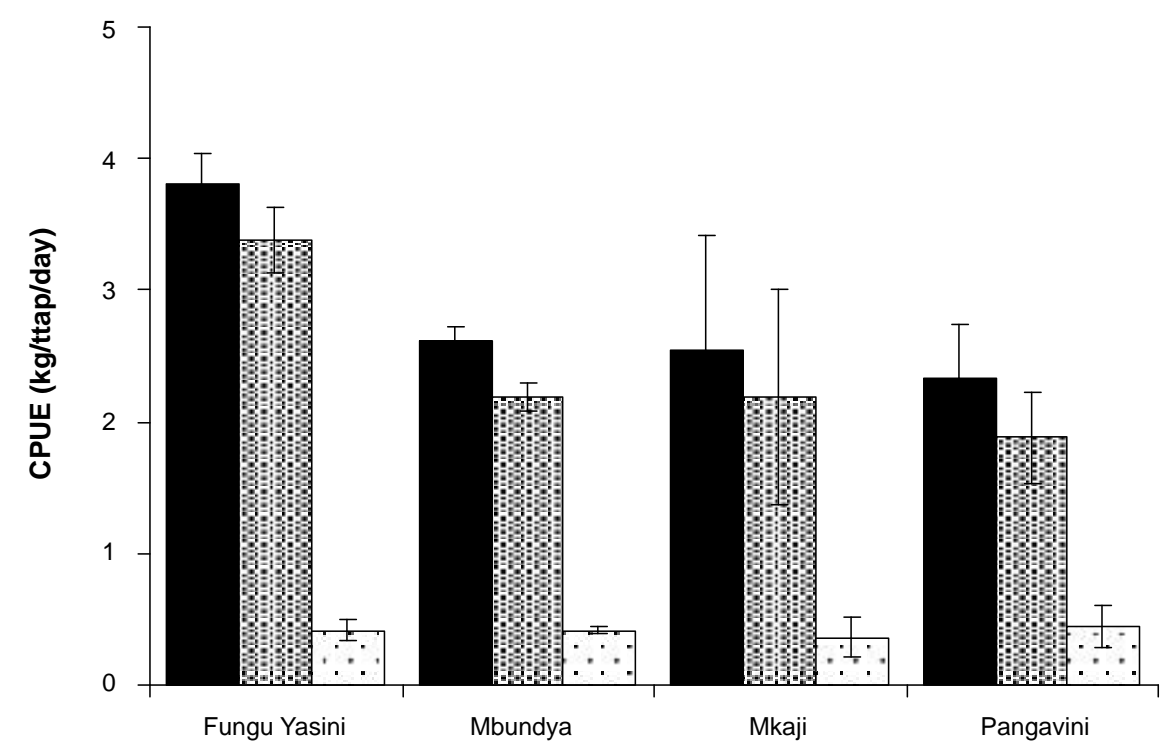

Fishing areas

b)

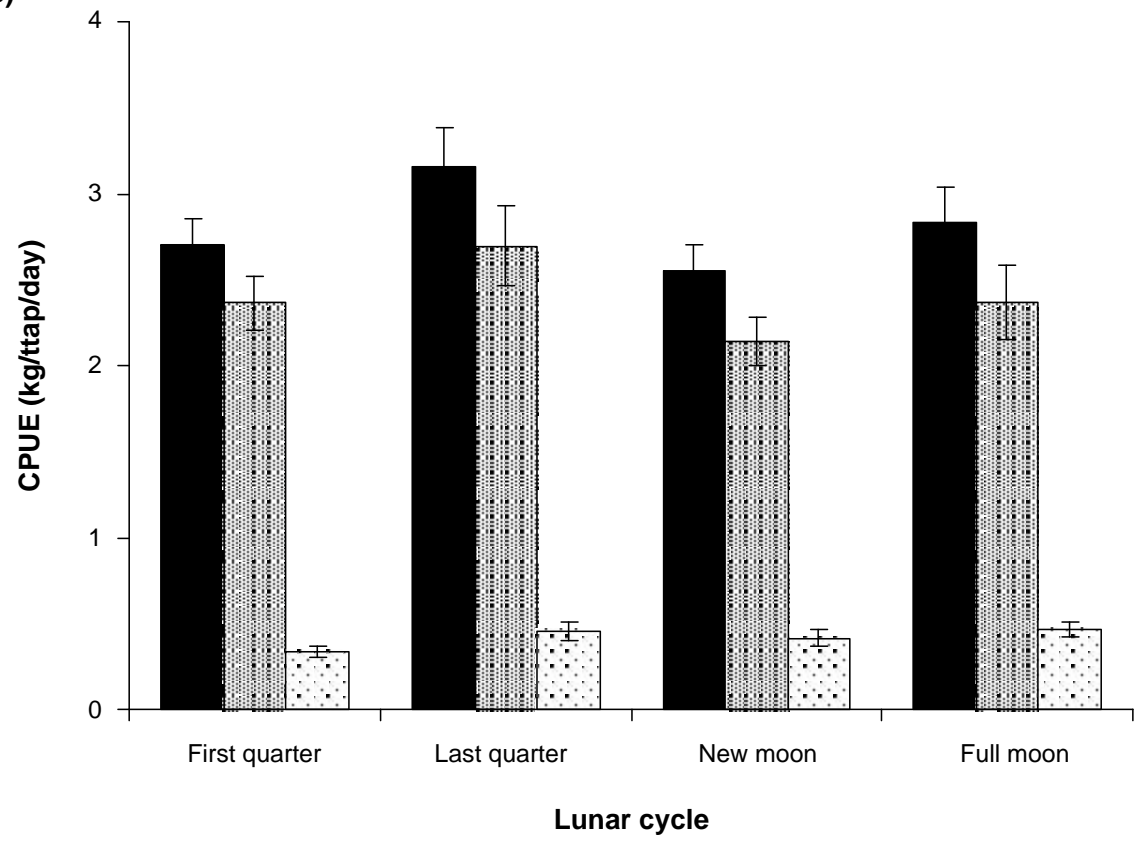

Fig. 3. (a) Spatial and (b) lunar cycle variations of mean CPUE for basket trap fishery within the Dar es Salaam Marine Reserves. Bars are standard errors (SE) of the mean 


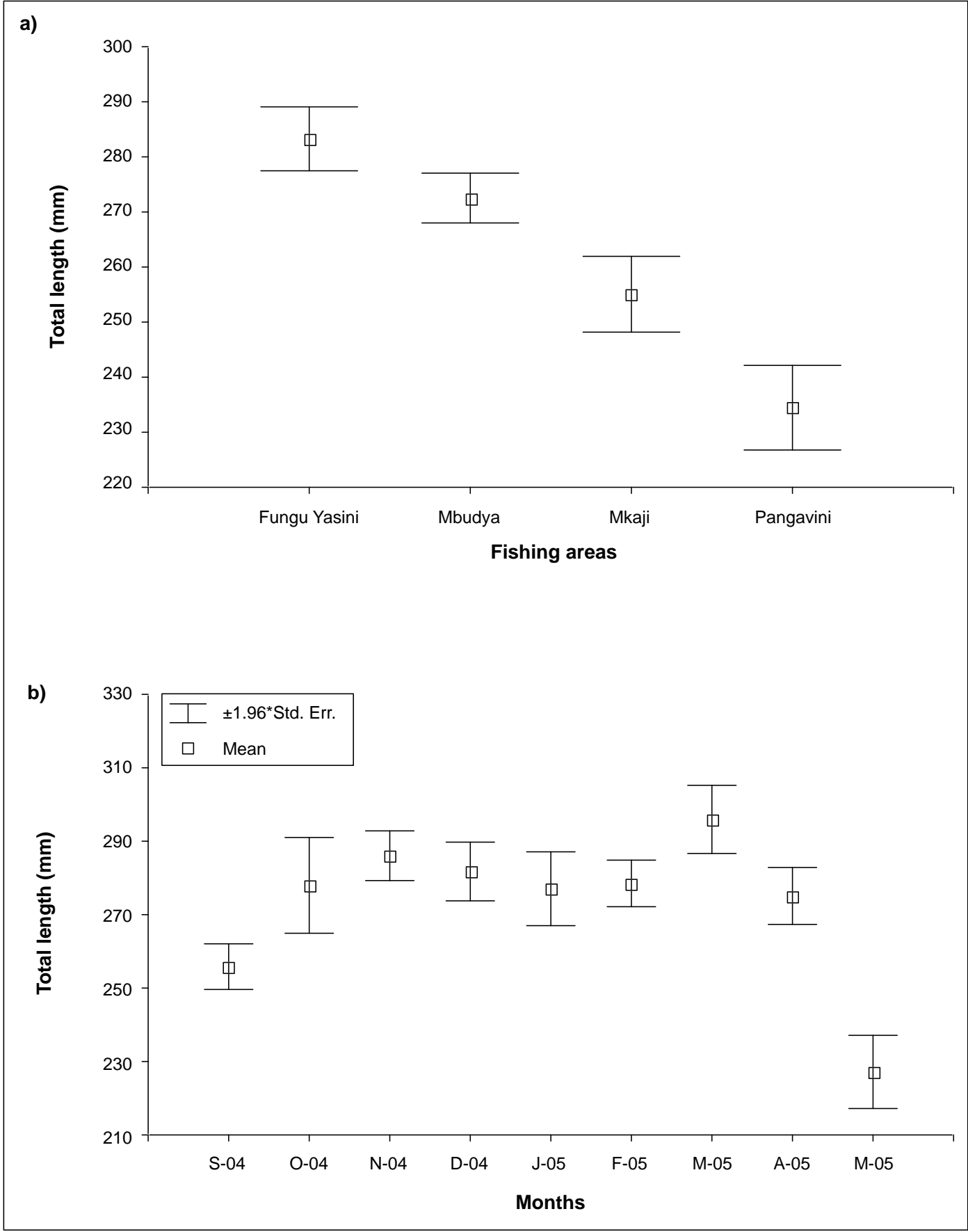

Figure 4. (a) Spatial and (b) monthly variations in mean TL of Siganus sutor caught in basket traps within the Dar es Salaam Marine Reserves. Bars are standard errors (SE) of the mean. 


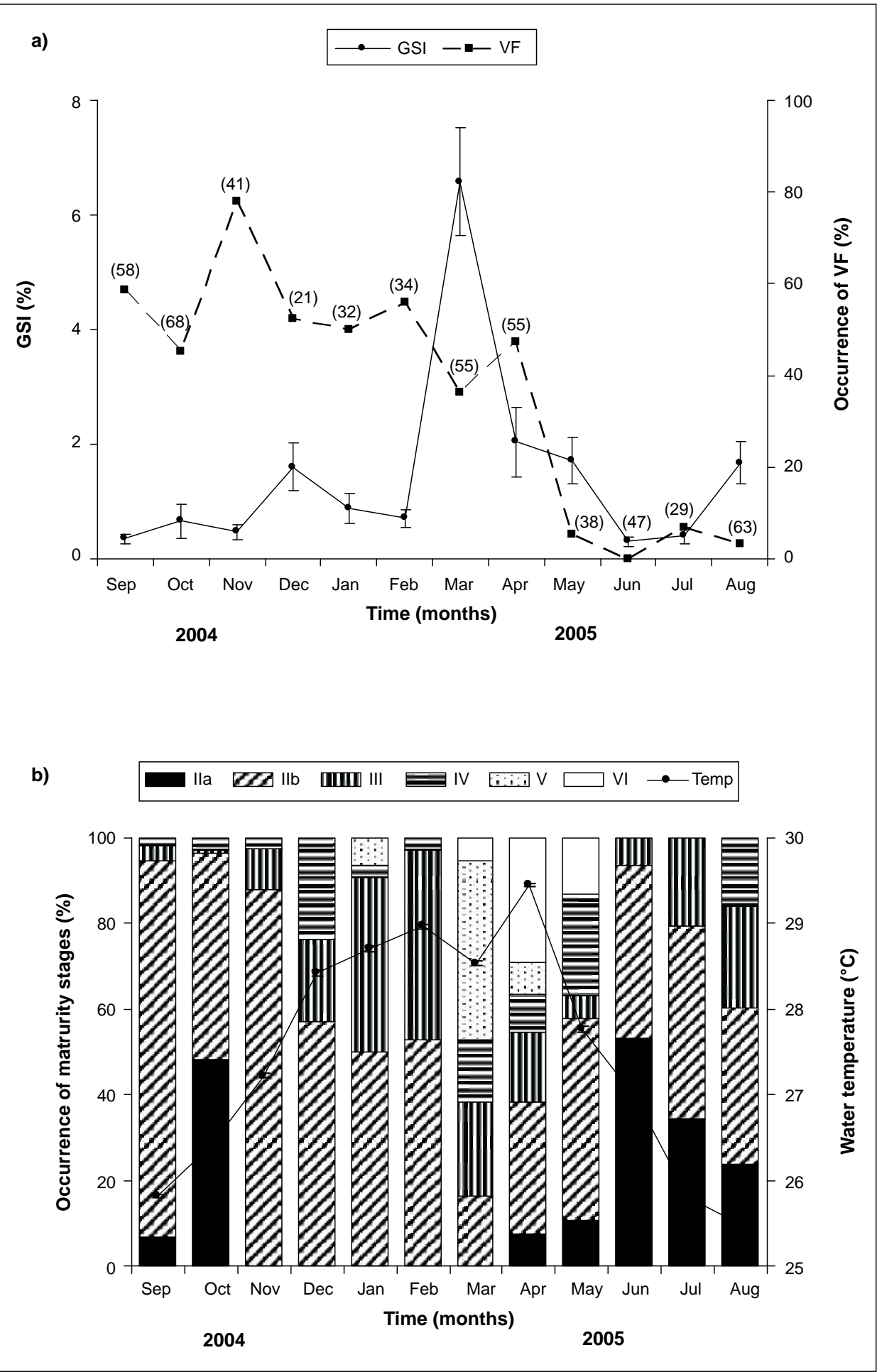

Fig. 5. (a) Monthly variations in mean gonadosomatic index (GSI) and occurrence of visceral fats (VF) and (b) seawater temperature and gonadal maturity stages of Siganus sutor (IIa = developing virgin, IIb = resting and recovering, III = early developing, IV = late developing, $\mathrm{V}=$ ripe and running, and VI = spent). Bars are standard errors (SE) of the mean and sample size are in brackets. 


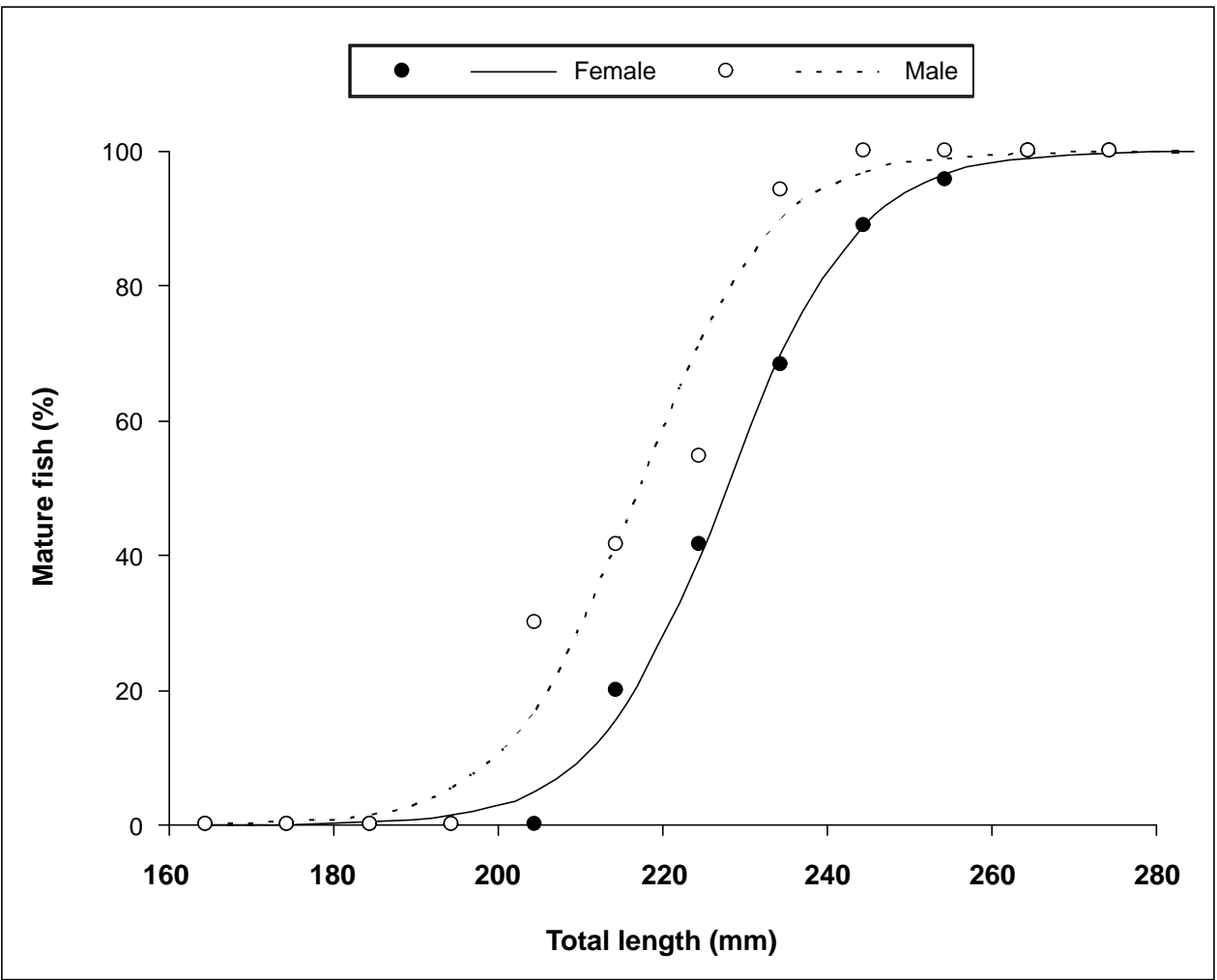

Fig. 6. Observed percentage of mature male and female Siganus sutor by $10 \mathrm{~mm}$ TL size classes fitted to a logistic function to estimate size at first sexual maturity given as 217.1 and $227.7 \mathrm{~mm}$ TL, respectively

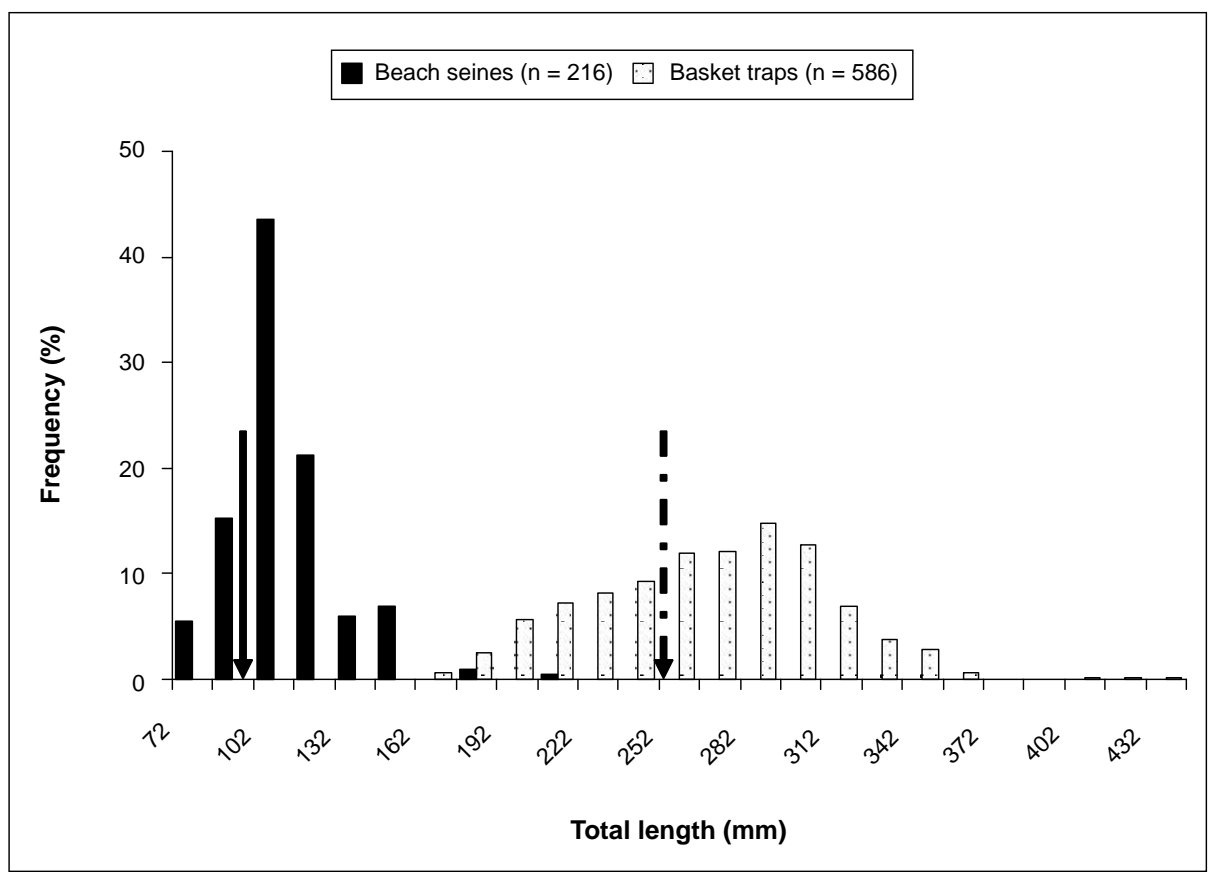

Fig. 7. Length-frequency distribution of Siganus sutor from beach seines and basket traps with arrows pointing sizes at first capture for both gear and $n$ indicates sample size 
in number of boats from sixteen in November 2004 to five in January 2005 forcing fishers to return to Unguja Island in Zanzibar.

A progressive decline in CPUE could partly be attributed to a sharp decline in fish lengths in May towards the end of fishing season, a phenomenon reported elsewhere by Koslow et al. (1988) and Alcala \& Russ (1990). These studies show that fishing affects fish size structure and that when fish sizes are smaller CPUE declines as fish weight increases exponentially with fish length. Unavailability of suitable bait due to rough seas coinciding with the onset of SE monsoon season might have contributed to the cease of basket trap fishery in DMRs (fishers pers.com.). Basket trap off fishing season (June - August) is normally characterised by lower water temperature, high wind energy, strong East African Coastal Current (EACC) and low solar insolation (McClanahan, 1988) that might have posed difficult conditions for the basket trap fishery.

Higher CPUE and large-sized S. sutor were observed from Fungu Yasini and Mbudya Island Marine Reserves. This may likely be attributed to spatial variations in fishing effort as a result of the distance separating fishing communities and marine reserves boundaries. For example, Fungu Yasini Marine Reserve, separated from the shore by a $5 \mathrm{~km}$ wide channel, had a significantly higher CPUE and large-sized S. sutor compared to Pangavini Island Marine Reserve situated at $1 \mathrm{~km}$ from the shore. It is also likely that frequent beach seining in the easily accessible areas adjacent to Pangavini Island might have reduced the abundance and size structure of S. sutor. Lugendo et al. (2005) indicated that shallow weedy habitats are frequently utilised by juveniles of commercially important fish species in marine embayment areas in Tanzania. Lunar cycle had no significant influence on the catchability of rabbitfishes by basket traps. Therefore, rabbitfishes either enter traps during daytime looking for food (i.e. bait) or at night seeking for shelter. Froese $e t$ al. (2003) described rabbitfishes as being diurnal herbivores, hiding in reef crevices during the night and browsing over reefs during the daytime.

The study demonstrated the effect of fishing gear on the size of target fish with beach seines predominantly catching sub-adult fish (107.3 \pm $1.3 \mathrm{~mm}$ TL) compared to basket traps $(262.0 \pm 1.8$ $\mathrm{mm}$ TL). Seine nets in Tulear region, southwest Madagascar, also target small rabbitfishes of average sizes $<100 \mathrm{~mm}$ that consumers did not favour (Laroche \& Ramananarivo, 1995). Beach seines were also found predominantly catching subadult fish in the Kenyan marine artisanal fisheries (McClanahan \& Mangi (2004). For a sustainable $S$. sutor fishery the gear should retain desirable sizes that do not undermine the sustainability of fish stocks. In this study, S. sutor size at first capture using basket traps was greater than the size at first sexual maturity (see Fig. 6) thus allowing fish to reproduce before they are caught.

$S$. sutor showed a skewed size dependent sex ratio with females dominating at larger size classes. Similar observations are reported for $S$. rivulatus and $S$. luridus, on the Lebanese coast (Bariche et al., 2003). Another study has suggested a higher growth rate of female $S$. sutor than male S. sutor (Ntiba \& Jaccarini, 1988). Ecologically, it makes sense for females to delay attaining sexual maturity because of significant positive relationship between body dimensions and egg production. Furthermore, Wootton (1998) stated that the cost of egg production is greater than that for sperm, thus requiring females to start reproducing when they have attained a larger size than males.

The occurrence of ripening and fully ripe fish between October and May, and peak GSI in March accompanied by a gradual decrease in the occurrence of VF were consistent with an extended spawning period of S. sutor. The depletion of body fat reserves in several fishes has been observed during gonadal maturation (Wootton, 1998). It is likely that oocyte recrudescence in $S$. sutor is related to high sea surface temperature extending from October to a maximum of $29.4^{\circ} \mathrm{C}$ in April (see Fig. $5 b$ ). Different spawning seasons of rabbitfishes in tropical and sub-tropical waters have been reported (Ntiba \& Jaccarini, 1990; Al-Ghais, 1993; Yeldan \& Avşar, 2000; Bariche et al., 2003). Takemura et al. (2004) suggested that reproductive seasonality of rabbitfishes appears to be affected by regional variation in environmental factors such as seawater temperature, photoperiod, and food abundance. Seawater temperature has been found to play a role in the timing and duration of spawning season of siganids in the Mediterranean Sea (Takemura et al., 2004). 
DMRs are no-take zones but fishing has not been banned and the most damaging fishing practice is the prevalent use of beach seines in the shallow adjacent areas. Reef-fish resource conservation based on MPAs with weak enforcement may be ill-suited for protection of species that are highly susceptible to overfishing such as reef fishes. This study has demonstrated the potential of basket trap fishery in DMRs as a method for sustainable exploitation of the siganids. One of the management options in DMRs could be a ban of beach seines causing growth overfishing and restricting $S$. sutor trap fishery during peak spawning season likely to cause recruitment overfishing. It is recommended that long term catch and effort data collection combined with fish size measurements be established in DMRs in order to allow estimates of maximum sustainable yield (MSY), a useful tool for fisheries management.

Acknowledgements-I thank the anonymous referees for useful comments on the manuscript, technicians in the Department of Aquatic Sciences and Fisheries for their assistance in the field and laboratory work, and fishers who participated in this project. This study was funded by the Western Indian Ocean Marine Science Association (WIOMSA), Marine Research Grant Programme (MARG) contract No. 12/2004.

\section{REFERENCES}

Alcala, A.C. \& Russ, G.R. (1990) A direct test of the effects of protective management on abundance and yield of tropical marine resources. J. Cons. Int. Explor. Mer 46: 40-47.

Al-Ghais, S.M. (1993) Some aspects of the biology of Siganus canaliculatus in the southern Arabian Gulf. Bull. Mar. Sci. 52: 886-897.

Bariche, M., Harmelin-Vivien, M.L. \& Quignard, J.P. (2003) Reproductive cycles and spawning periods of two Lessepsian siganid fishes on the Lebanese coast. J. Fish Biol. 62: 129-142.

Bwathondi, P.O.J. (1981) The culture of rabbitfish Siganus spp. in Tanzania. Stockholm: IFS. 35 pp.

Duponchelle, F. \& Panfili, J. (1998) Variations in age and size at maturity of female Nile tilapia, Oreochromis niloticus, populations from manmade lakes of Côte d'Ivoire. Env. Biol. Fish., 52: 453-465.
Fischer, W. \& Bianchi, G. (eds.) (1984) FAO species identification sheets for fishery purposes. Western Indian Ocean (Fishing Area 51). Rome: Danish International Development Agency (DANIDA)/ Food and Agricultural Organisation of the United Nations (FAO). Vols. 1-6: pp. var.

Froese, R., Pauly, D. \& Woodland, D. (2003) "FISHBASE" (On-line). FISHBASE World Wide Web electronic publication. Accessed at http:// www.fishbase.org/.

Kamukuru, A.T., Hecht, T. \& Mgaya, Y.D. (2005) Effects of exploitation on age, growth and mortality of the blackspot snapper, Lutjanus fulviflamma (Lutjanidae) at Mafia Island, Tanzania. Fish. Manage. Ecol. 12: 45-55.

Kamukuru, A.T. \& Mgaya, Y.D. (2004) Effects of exploitation on reproductive capacity of blackspot snapper, Lutjanus fulviflamma (Pisces: Lutjanidae) in Mafia Island, Tanzania. Afr. J. Ecol. 42: 270280.

Kamukuru, A.T., Mgaya, Y.D. \& Öhman, M.C. (2004) Evaluating a marine protected area in a developing country: Mafia Island Marine Park, Tanzania. Ocean Coastal Manage. 47: 321-337.

Kaunda-Arara, B. \& Rose, G.A. (2006) Growth and survival rates of exploited coral reef fishes in Kenyan Marine Parks derived from tagging and length-frequency data. Western Indian Ocean J. Mar. Sci. 5: 17-26.

King, A. (2000) Managing without institutions: the role of communication networks in governing resource access and control. Ph.D. Thesis. Coventry: University of Warwick. $251 \mathrm{pp}$.

Koslow, J.A., Hanley, F. \& Wicklund, R. (1988) Effects of fishing on reef fish communities at Pedro Bank and Port Royal Cays, Jamaica. Mar. Ecol. Prog. Ser. 43: 201-212.

Laroche, J. \& Ramananarivo, N. (1995) A preliminary survey of the artisanal fishery on coral reefs of the Tulear Region (southwest Madagascar). Coral Reefs 14: 193-200.

Lugendo, B.R., Pronker, A., Cornelissen, I., de Groene, A., Nagelkerken, I., Dorenbosch, M., van der Velde, G. \& Mgaya, Y.D. (2005) Habitat utilisation by juveniles of commercially important fish species in a marine embayment in Zanzibar, Tanzania. Aquat. Living Resour. 18: 149-158.

McClanahan, T.R. (1988) Seasonality in East Africa's coastal waters. Mar. Ecol. Prog. Ser. 44: 191199.

McClanahan, T.R. \& Mangi, S.C. (2001) The effect of closed area and beach seine exclusion on coral reef fish catches. Fish. Manage. Ecol. 8: 107-121.

McClanahan, T.R. \& Mangi, S.C. (2004) Gear-based management of a tropical artisanal fishery based 
on species selectivity and capture size. Fish. Manage. Ecol. 11: 51-60.

Ntiba, M.J. \& Jaccarini, V. (1988) Age and growth parameters of Siganus sutor in Kenyan marine inshore water, derived from numbers of otolith microbands and fish lengths. J. Fish. Biol. 33: 465-470.

Ntiba, M.J. \& Jaccarini, V. (1990) Gonad maturation and spawning times of Siganus sutor off the Kenya coast: evidence for definite spawning seasons in tropical fish. J. Fish. Biol. 37: 315-325.

Ntiba, M.J. \& Jaccarini, V. (1992) The effect of oocytic atresia on fecundity estimates of the rabbit fish Siganus sutor (Pisces: Siganidae) of Kenyan marine inshore waters. Hydrobiologia 247: 215-222.

Pauly, D. (1984) Length-converted catch curves: a powerful tool for fisheries research in the tropics (Part II). ICLARM Fishbyte 2: 17-19.

Pauly, D., Watson, R. \& Alder, J. (2005) Global trends in world fisheries: impacts on marine ecosystems and food security. Philos. Trans. R. Soc. Lond B Biol. Sci. 360: 5-12.

Roxburgh, T., Morton, I., Rumisha, C. \& Francis, J. (eds) (2002) An Assessment of the stakeholders and resource use in the Dar es Salaam Marine
Reserves system. ICRAN/WIOMSA. Nairobi: Regal Press. 102 pp.

Sibert, J., Hampton, J., Kleiber, P. \& Maunder, M. (2006) Biomass, size, and trophic status of top predators in the Pacific Ocean. Science 314: 1773-1776.

Takemura, A., Rahman, M.S., Nakamura, S., Park, Y.J. \& Takano, K. (2004) Lunar cycles and reproductive activity in reef fishes with particular attention to rabbitfishes. Fish Fish. 5: 317-328.

United Republic of Tanzania (URT) (2005) Dar es Salaam Marine Reserves General Management Plan. Board of Trustees for Marine Parks and Reserves, Tanzania Marine Parks and Reserves Unit, $56 \mathrm{pp}$.

Woodland, D.J. (1990) Revision of the fish Family Siganidae with descriptions of two new species and comments on distribution and biology. Honolulu: Bishop Museum, 136 pp.

Wootton, R.J. (1998) Ecology of teleost fishes. Kluwer Academic Publishers, London, 386 pp.

Yeldan, H. \& Avşar, D. (2000) A preliminary study on the reproduction of the rabbitfish (Siganus rivulatus (Forsskål, 1775) in the north-eastern Mediterranean. Turk. J. Zool. 24: 173-182. 